\title{
Bacteriological Risk Assessment of Borehole Sources of Drinking Water in Some Part of Port Harcourt Metropolis of Niger Delta, Nigeria
}

\author{
Azuonwu Obioma*1, Ihua Nnenna ${ }^{1}$ and Ohwondah Golden ${ }^{2}$ \\ ${ }^{1}$ Department of Medical Laboratory Science, Faculty of Science, River State University, Nkpolu Oroworukwo Port Harcourt, Nigeria \\ ${ }^{2}$ Department of Public Health, Rivers State Ministry of Health, Nigeria \\ *Corresponding author: Azuonwu O, Department of Medical Laboratory Science, Faculty of Science, River State University, Nkpolu \\ Oroworukwo Port Harcourt, Nigeria, Email.: bimajacobs@yahoo.co.uk
}

\section{ARTICLE INFO}

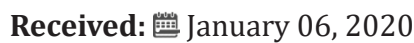

Published: 慧 January 21, 2020

Citation: Azuonwu Obioma, Ihua Nnenna, Ohwondah Golden. Bacteriological Risk Assessment of Borehole Sources of Drinking Water in Some Part of Port Harcourt Metropolis of Niger Delta, Nigeria. Biomed J Sci \& Tech Res 24(4)-2020. BJSTR. MS.ID.004093.

Keywords: Microbial Risk; Assessment; Borehole Water; Public Health; Poor Sanitation; Poor Personal Hygiene

Abbreviations: MPN: Most Probable Number; DFID: Department of International Development; WHO: World Health Organization; UNICEF: United Nations International Children Emergency Fund; FIB: Faecal indicator Bacteria

\section{ABSTRACT}

The potability of drinking water across the globe has increasingly continued to be in doubt, due to the problem of microbial contamination, high saline content and external human activity stress, thus making the water quality questionable and no longer guaranteed as safe anymore for human consumption. Nonetheless, with the increasing demand for water, irrespective of its potability; borehole has become a common source of drinking water in many countries across the globe, even in the country of this present study. Poor quality of drinking water has contributed to the increase in morbidity, due to water borne diseases especially in children and immuno-compromised individuals thereby increasing the burden of diseases in the region. Water borne disease is a huge concern and a major public health problem, because it affects the health of an individual in most cases when it is ingested into the body via faecal-oral route therefore; the need for the evaluation of microbial contamination of borehole water remains paramount and thoughtful towards good health and safety of all and Sunday. This present study was aimed at conducting microbial risk assessment of borehole sources of drinking water; specifically evaluating coliform count/faecal indicator bacteria of borehole water in Diobu area of Port Harcourt, Rivers State, Nigeria.

A total of 30 water samples were collected at random from ten different boreholes at the various locations at three different periods of time (Morning, Afternoon and Evening) respectively. Microbial analysis of the water sample was processed by testing for total coliform count (faecal indicator bacteria) using the heterotrophic plate counts and the most probable number (MPN) techniques as presumptive test. Also, morphological characteristics and biochemical identifications were performed according to standard microbiological operation technique. The results of the mean heterotrophic bacterial count of the borehole water sampled from ten different locations revealed that samples were all contaminated at varying degrees, though some had zero most probable number. Nonetheless, there was no significant mean bacterial count difference as well as an association ( $p>0.05)$ among the ten different boreholes sampled however, a variation was observed $(p<0.05)$ between the seasonal session (period/time of collection). Nevertheless, poor sanitary completion of the boreholes leads to contamination of borehole water, even as proximity of some boreholes to solid waste dumpsites and animal droppings littered around remains a source of concern, furthermore, lack of periodic maintenance culture as observed during physical visitation may probably be another factor that should be considered, however, regular quality monitoring and assessment of Public Health risk outcome would obvious help to reduce the microbial risk infection in the locality. 


\section{Introduction}

Safe drinking water is still a challenging public health issue in the midst of lots of borehole water in-use in our various communities; thus, these further justify the trend that the integrity of such a source of drinking water might not be guaranteed in the end. Access to safe drinking water is a human right; and it is one of the basic requirements for good health as reported by UNICEF/ WHO [1]. This has resulted to more level of awareness campaigns and Public Health echo regarding quality of borehole water. WHO in conjunction with UNICEF [2] developed an indicator known as "use of an improved source", this indicator is used to monitor access to safe drinking water globally? Nevertheless, this indicator does not really measure the quality of water [2]. Furthermore, water sources are either from the periphery called surface water or underneath referred to as ground water. Globally, ground water is the largest and most important source of potable water [3]. Also, according to Department of International Development (DFID) Strategies for Achieving the International Development Targets [4], an estimate of 1.5 billion people has ground water as their daily potable water source and has proved to be the most reliable source for meeting rural water demand in the sub-Saharan Africa as reported by some studies [5,6].

Owing to failure of governments to meet the ever-increasing water demand, most people resort to groundwater sources such as boreholes as an alternative water source. Thus, humans can access groundwater through a borehole, which is drilled into the aquifer for industrial, agricultural and domestic use. Access to water does not mean access to safe water, according to United Nations International Children Emergency Fund (UNICEF) and World Health Organization (WHO) classified Nigeria among group of ten (10) countries which is about two-thirds of the world population; without access to improved drinking water sources. Statistics have shown that over sixty million Nigerians have no access to potable water $[2,7]$. It is strongly believed that such trend will definitely favour the geometric increase of water borne, and water wash epidemic outbreaks in our communities, if urgent multi-sectorial approach is not deployed to save the situation in good time. Nonetheless, borehole water is a form of groundwater that is usually believed to be a "safe source" of drinking water because it comes with low microbial load thus; it requires little or no need of treatment before drinking the water, nevertheless, it is strongly believed that this advantage is because of long retention time and natural filtration capacity of aquifers according to Aiyesammi et al. [8].

On the other hand, groundwater sources are commonly susceptible to contamination, which may reduce its quality. In general, groundwater quality varies from place to place, sometimes depending on seasonal changes as revealed by Trivede et al. also, Vaishali \& Punita $[9,10]$, and the types of soils, rocks and surfaces through which it runs through [11,12]. Naturally occurring contaminants are present in the rocks and sediments. In addition, human activities can alter the natural composition of groundwater through the disposal or dissemination of chemicals and microbial matter on the land surface and into soils, or through injection of wastes directly into groundwater. Industrial discharges [13], urban activities, agriculture [14] groundwater plumage and disposal of waste [15] can potentially affect the groundwater quality, even as pesticides and fertilizers applied to lawns and crops can accumulate and migrate to the water tables thus, affecting both the physical, chemical and microbial quality of water respectively. Borehole is extensively used in Nigeria with over 120,000 million people using it as a source drinking water, because it is probably suggested to be cheap, accessible and easy to manipulate by the local people in remote communities. Also, pit latrines as well as water closet are the most common toilet systems used in the area where this present study was undertaken as at the time of sample collection.

Nonetheless, it is believed that the poor sanitary toilet system poses a great risk on the microbial quality of drinking water. A septic tank can introduce bacteria to water; pesticides and fertilizers that leak into farmed soils can eventually end up in the water drawn from a borehole. Poor sanitary completion of boreholes may lead to contamination of groundwater. Proximity of some boreholes to solid waste dumpsites and animal droppings being littered around them [16] could also contaminate the quality of groundwater. Therefore, groundwater quality monitoring and testing is of paramount importance both in the developed and developing world [17]. In addition, high salinity and hardness outside microbial problems have also been reported in groundwater. Water quality problems have partly been associated with inadequate sanitation as reported by Van [18]. However, study has shown that elevated microbial load seen in drinking water could be affected by climate weather like high temperature. This explained the effect of temperature on the rate of microbial replication [16]. Furthermore, the fact that; potential cause of high coliform count is traceable to location, and proximity of certain boreholes to toilet systems like pit latrines as well as poor sanitary completion of boreholes, as this would obviously lead to contamination of groundwater, hence it cannot be overemphasized as a huge sources of contamination.

In addition, there are environmental sources like soil or biofilms which can affect borehole water by its contamination with microbes. Nonetheless, microbial contamination of borehole water is linked to the depth of the borehole as reported by previous studies [11,12]. Though the depths of the various borehole studied were not known, borehole depth remains critical and very imperative factor in the investigation of bacterial contaminants in borehole water. A recommended minimum depth of a borehole is $40 \mathrm{~m}$. As ground water passes through saturated sand, as well as non-fissured rock, microbial contaminants tend to be removed within the first $30 \mathrm{~m}$ depth however, in unsaturated zone, no more than $3 \mathrm{~m}$ may be necessary to purify groundwater. However, in fractured aquifer, microbial contaminants can rapidly pass through the unsaturated zone to the water table [14]. Most boreholes are constructed using an electrical device such that the water is 
pumped into pipes for distribution. Old and rusty pipes affect the quality of water by allowing leakage of microbial contaminants into the borehole [19]. Furthermore, microbial contaminants in borehole water might pose a serious health threat to individuals after consumption. These microbial contaminants are pathogenic in nature and possess various genetic determinants some of which are harmful i.e. the virulent strains like E. coli strains (E. coli 0157:H7 and E. coli 0104:H4) known to cause diseases in man [20].

It is strongly believed that virulence of Enterohaemorrhagic Escherichia coli and established that animals are the natural reservoir hosts of Enterobacteriaceae and indiscriminate release of faeces within the surrounding contributes to the presence of these bacteria in the environment. Nevertheless, it is firmly suggested that provision of potable drinking water, and good sanitary habit is crucial for all, particularly among vulnerable groups like children and immuno-compromised individuals, because unsafe drinking water could add to several water borne diseases however, this challenge is only common in developing countries as documented by Mark et al. [21], who reported that there are over one billion annual incidences of diarrhoea and other myriad of gastroenteritis infections that are linked to lack of access to potable water. Borehole water is prone to physical, chemical as well as microbial contaminants. This present study considered only the bacteriological quality of the borehole water in Port Harcourt. Borehole water been a ground water should be one of the best type of water recommended for drinking free from contaminants as opposed to surface water; however, the quality of borehole water in recent time have deteriorated significantly thereby, faulting the quality of borehole as it was initially perceived.

The microbial contamination of borehole water has posed health threats and complications with some imminent waterborne disease outbreaks in some regions, especially in the developing countries like Nigeria. The issue of microbial contamination in borehole water is of public health concern because most of the water for consumption in these regions (developing countries) is from borehole, either from government facilities or private/homemade facilities as such, the quality of borehole water should be guaranteed been the common source of drinking water available. Also, since microbial quality of borehole water is related to sanitary habits and environmental activities like agricultural practices, storage tanks which can be controlled; therefore, it is important to evaluate the quality of these boreholes to ascertain the presence of pathogenic microbes. Nonetheless, water remains the major source of transmission of enteric pathogens in developing countries. According to Federal Ministry of Health, Nigeria (1991) [22], notified cases are mostly in under five year (s) old children. Water born infections like gastroenteritis characterized with acute diarrhoea have a high incidence and this can be attributed to lack of the availability of safe drinking water.

Alabi et al. [23] studied some pathogenic agents associated with infantile diarrhoea in Nigeria; they reported 48.6\%, 30.6\%,
8.2\% 6.9\% for bacteria, viruses, enteric parasites (protozoa and helminths) and of dual aetiology respectively. The construction of borehole involves laying of pipes underground; these pipes are supposed to be checked periodically i.e. periodic maintenance also; drainages ought to be far from water pipes to avoid cross contamination. The quality of domestic water supplies and the potability of the drinking water could be in doubt, due to the afore-mentioned reasons thus, both the water for home use, and the commercially sold water quality is not guaranteed. With the increasing demand for water in Nigeria, most times the people only demand for quantity and not quality; that is to say an individual can have access to water but the quality of the water is poor, this could in-turn cause water borne disease which is a major public health problem therefore, the need for risk assessment of microbial contamination of borehole water cannot be over stressed. The prime health risk of water borne diseases is from consumption of faecal contaminated water i.e. faecal oral route of transmission; the faecal material contains pathogenic microbes that can cause infectious diseases. These diseases range from cholera, other diarrheal diseases, dysenteries, and enteric fevers. Nonetheless, epidemiological evidence of water borne diseases have been reported by Federal Ministry of Health of Nigeria (1991) on diarrhoea, haemorrhagic colitis [22] as well as Aeromonassobria in chlorinated drinking water supplies [23].

In addition, some outbreak investigations have suggested the presence of microbial contaminants in drinking water, as seen in a Uganda based study by Legros et al. [24] on the epidemiology of cholera outbreak relating the effect of faecal oral route of transmission, and the need for a good hygiene and potable drinking water for consumption. In the same view, a previous study by LeChevallier et al. [25] reported same. Furthermore, other studies are evident of poor water quality consumption resulting to health issues, due to the susceptibility of the individuals to the danger and risk of water borne infections [26]. Globally, over two billion morbidity and mortality cases due to water borne diseases have been reported, with over 50,000 death rate per day and about four million child mortality rates (under five children) in developing countries [27,28]. Against the above backdrop, the present study was aimed at investigating the bacteriological risk quality of borehole sources of drinking water in Diobu area of Port Harcourt. These would specifically be evaluating the coliform count as a critical indicator bacteria of water pollution or contamination. It is, therefore, firmly believe that data generated would help to uncover how potable is the drinking water source in the studied location. Also, it will also guide and direct the policy makers and especially Health agencies towards underpinning their strategies and policies towards improving the water treatment and sanitation outcome for the good of all.

\section{Methodology}

Faecal indicator bacteria (FIB) and source indicator (sanitary inspection) are tools for assessing safe and potable drinking water. 
The recommended Guideline for Drinking-water Quality (GDWQ) ( $4^{\text {th }}$ Edn.), by WHO that include criteria for assessing health risks and setting targets for improving water safety. Here, the WHO GDWQ recommended E. coli was used to assess faecal contamination in drinking water using faecal indicator bacteria (FIB) since direct measurement of pathogens is complex but techniques for assessing are well established and widely applied. The WHO guideline value for E. coli ("none detected in any 100-ml sample") [25].

\section{Risk Classification of Faecal Indicator Bacteria (FIB) in Drinking Water}

A commonly used risk classification outcome was based on the number of indicator organisms in a $100 \mathrm{ml}$ sample, as shown below: $[29,30]$.

\section{$<1$, "very low risk"}

1-10, "low risk"

10-100, "medium risk".

$>100$, "high risk" or "very high risk"

Nonetheless, faecal indicator bacteria (FIB) is imperfect and the level does not necessarily equate to risk [31]; since quality varies both temporally and spatially, occasional sampling may not accurately reflect actual exposure. As a result, sanitary inspection is a complementary approach in the assessment of safe drinking water, it involves the identification of hazards and other measures like risk management through hygienic check of a drinking water source, as well as its surrounding environment [30,32].

\section{Study Location/Area}

Diobu is a densely populated area within the neighborhood of Port Harcourt, Rivers State of Nigeria. It is located within the Port Harcourt metropolis. Diobu consist of three focal extensions, which includes Mile 1, Mile 2 and Mile 3. Bordering New GRA to the North, D-line to the North-East, Rivers State University to the North-West, Old GRA to the East, Kidney Island to the South-East, and Eagle Island to the South-West. The coordinates of Diobu are: $4^{\circ} 47^{\prime} 24^{\prime \prime} \mathrm{N}$, 659'36"E (Latitude:4.772152; Longitude: 6.994514) and time zone is WAT (UTC+1). The topography surrounding environment of Port Harcourt is a soil type which has not been consolidated; it is moderately porous and made up of permeable sands which has the tendency to drain fast; also, lenticular clays and shales at depth of up to $50 \mathrm{~m}$ [33]. Thus, the soil within the Port Harcourt metropolis makes the groundwater within this region prone to contamination. There are lots of commercial activities around the Diobu area; most of the commercial activities existing in Diobu are brought about by its numerous market place. The area is home to Mile One market, one of the largest open-air markets in Port Harcourt, where everything from clothes, household goods to foodstuffs are sold. In the absent of valid statistics, it has been estimated that the Timber market in Diobu have over 5000 businesses providing employment via small and median scale enterprises for over one million persons including traders, carpenters, wood dressers and labourers, among others. Though, Diobu ranks among most commercially vibrant places in the city, about a two-third of its residents live below the poverty level (Figure 1).

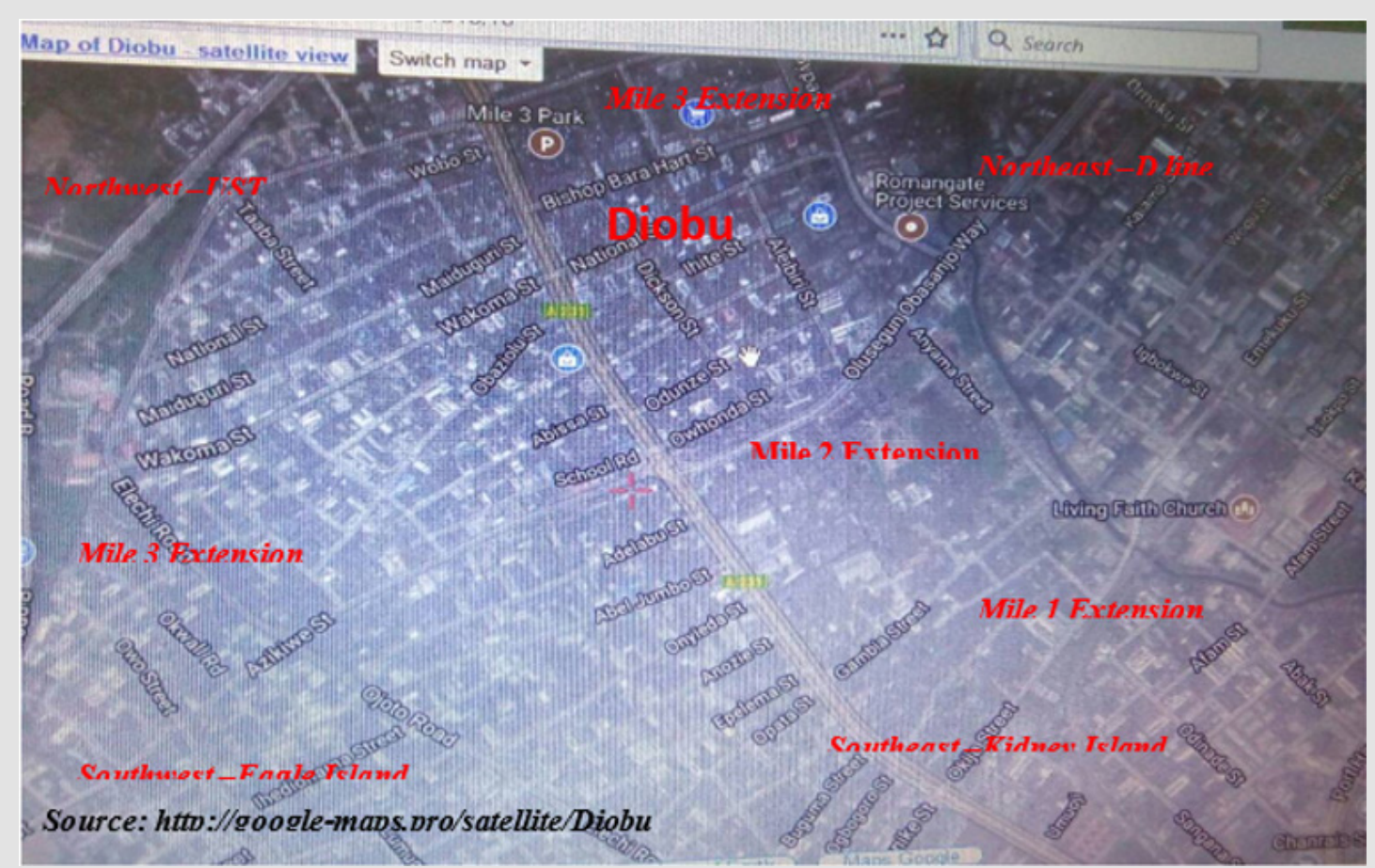

Figure 1: Map of Study Area (Diobu, Port Harcourt, Rivers State, Nigeria). 


\section{Sample Collection}

Borehole water samples were collected from ten different streets boreholes within the Diobu area of Port Harcourt Metropolis namely: Azikiwe, Echue, Elechi, Ikon, Lumumber, Obidianso, Naka, Obobo (lane), Uyo and Wobo Street, all within the same geographical location. Sample collection was aseptically carried out with the use of sterile sample bottles and sampling procedure involved the use of a cotton wool soaked $70 \%(\mathrm{v} / \mathrm{v})$ ethanol used to sterilize the nozzle of the tap from which sample were collected. The tap was allowed to run for two minutes before sterile $250 \mathrm{ml}$ screw capped plastic bottles where carefully uncapped and filled from a gentle flow of water and recapped immediately and transported to the laboratory in an ice park for analysis [34]. A total of 30 samples were collected, sample collection was collected in three sessions (period/time)-morning, afternoon and evening.

\section{Laboratory Analysis}

Microbial analysis of the water sample was assayed by testing for total coliform count (faecal indicator bacteria) using the heterotrophic plate counts and the most probable number techniques (MPN). Heterotrophic plate count involved spreading of the sample on a plated media; a serial dilution of 1:10 was employed. With the use of a sterilized spreader, the sample was first inoculated on the nutrient agar i.e. primary inoculum and then spread out by streaking; after an overnight incubation at a temperature of $37^{\circ} \mathrm{C}$. The plated media were in triplicates for each sample and an average value was taken from discrete colony count which became the total heterotrophic count for aerobes. Furthermore, discrete colonies were sub-cultured to obtain a pure culture [34].

\section{Total Coliform Count}

Total Coliform count was carried out firstly, to establish the presence of microbial contamination in the water samples using a presumptive test method to identify the most probable value [35]. Secondly, a confirmatory test which involved sub-culturing of a positive presumptive test sample on a MacConkey agar media at 37 oc for 48 hours. The resultant colonies were further identified using some of the biochemical identification system as well as morphological characteristics based on colonial appearance and gram staining reaction according to Cheesbrough M [34].

\section{Presumptive Test Analysis of Most Probable Number}

Presumptive test used in this study was multiple tube method i.e. Most Probable Number (MPN) for the estimation of total coliform bacteria and faecal coliform bacteria in the water samples. The MPN involved fifteen (15) test tubes for each sample (i.e. $10 \mathrm{ml}, 1 \mathrm{ml}$ and $0.1 \mathrm{ml}$ ). Double strength MacConkey broth was used for $10 \mathrm{ml}$ sample while the other set of tube containing the single strength MacConkey broth are $1 \mathrm{ml}$ and $0.1 \mathrm{ml}$ of the water sample. The test tubes were shaken to mix the contents properly and incubated at $37 \mathrm{C}$ for 24 hours. After incubation, the test tubes were examined and those that produce acid and gas, the tubes were further incubated for 48 hours, after which they were then observed for positive and negative reaction and the results were again recorded. Acid production was indicated by changing the colour of the medium from purple to yellow and gas production by collecting of gas in inverted Durham tubes. Tubes that were found to produce acid and gas were tallied according to their number of occurrence and then referred to the MacCardy table to estimate the most probable number of coliforms found in each tube containing the water sample in the broth [35]. This was the presumptive test for coliform bacteria in water [35].

\section{Pathogen Identification through Biochemical Test}

Biochemical test used for identification includes catalase test to differentiated catalase producers from non-catalase producers (enzymatic slide method), coagulase test was used to different Staphlococcus auerus from other species (enzymatic slide method); other biochemical tests like indole test, oxidase, citrate utilization test and sugar fermentation test following chromogenic activities and sugar utilization as energy source. These biochemical procedures were performed following the conventional methods according to Cheesbrough, American Public Health Association, Fawole \& Oso (2001) also, Burnett \& Beuchat [34-37].

\section{Statistical Analysis}

Statistical analysis for this study includes: Mean, Standard Deviation, paired t-test, ANOVA and Correlation statistics were used at $\mathrm{p}<0.05$ using SPSS version 21. Table and Charts/Figures were used for data presentation. Furthermore, normal distribution of data was tested with Kolmogorov-Smirnov and the data showed normality ( $\mathrm{p}>0.05)$.

\section{Results}

A total of 30 samples collected from the ten different street boreholes at the various stipulated locations at three sessions (different times: morning 8-10am, afternoon 12-2pm and evening 4-6 $\mathrm{pm}$ ) had the results shown below. The probable organism isolated in this study using various biochemical identification tests includes Proteus spp, E. coli, Pseudomonas spp, Enterobacterspp, Staph spp and Klebsiella (Figure 2). The finding from this study had the mean heterotrophic bacterial count $\mathrm{CFU} / \mathrm{ml}$ of the borehole water sampled from ten different locations collected in the morning hours revealed as; $6.6 \times 10^{3}, 2.6 \times 10^{4}, 8.5 \times 10^{2}, 1.4 \times 10^{5}, 3.9 \times 10^{3}, 2.4 \times 10^{4}$, $8.0 \times 10^{2}, 6.5 \times 10^{2}, 2.4 \times 10^{4}$ and $7.5 \times 10^{3}$ for streets of Wobo, Lumumber, Uyo, Obidianso, Ikon, Obobo lane, Elechi, Azikiwe, Nanka and Echue respectively with a grand mean of $1.08 \times 10^{0}$ (Figure 3). Furthermore, the samples collected in the afternoon showed mean heterotrophic counts of $5.1 \times 10^{3}, 2.1 \times 10^{4}, 6.5 \times 10^{2}, 1.0 \times 10^{4}, 2.6 \times 10^{3}$, $2.0 \times 10^{4}, 4.5 \times 10^{2}, 5.5 \times 10^{2}, 1.7 \times 10^{4}$ and $5.9 \times 10^{3}$ for streets of Wobo, Lumumber, Uyo, Obidianso, Ikon, Obobo lane, Elechi, Azikiwe, Nanka and Echue in that order; a grand mean of $8.32 \times 10^{5}$ (Figure 4). Also, the mean heterotrophic bacterial count $\mathrm{CFU} / \mathrm{ml}$ of the borehole water sampled from ten different locations collected in the 
evening showed $5.1 \times 10^{4}, 1.13 \times 10^{5}, 6.67 \times 10^{3}, 1.33 \times 10^{5}, 2.06 \times 10^{5}$, mumber, Uyo, Obidianso, Ikon, Obobo lane, Elechi, Azikiwe, Naka $5.83 \times 10^{3}, 5.16 \times 10^{5}, 5.70 \times 10^{5}$ and $5.83 \times 10^{4}$ for streets of Wobo, Lu- $\quad$ and Echue respectively with a grand mean of $7.86 \times 10^{5}$ (Figure 5 ).

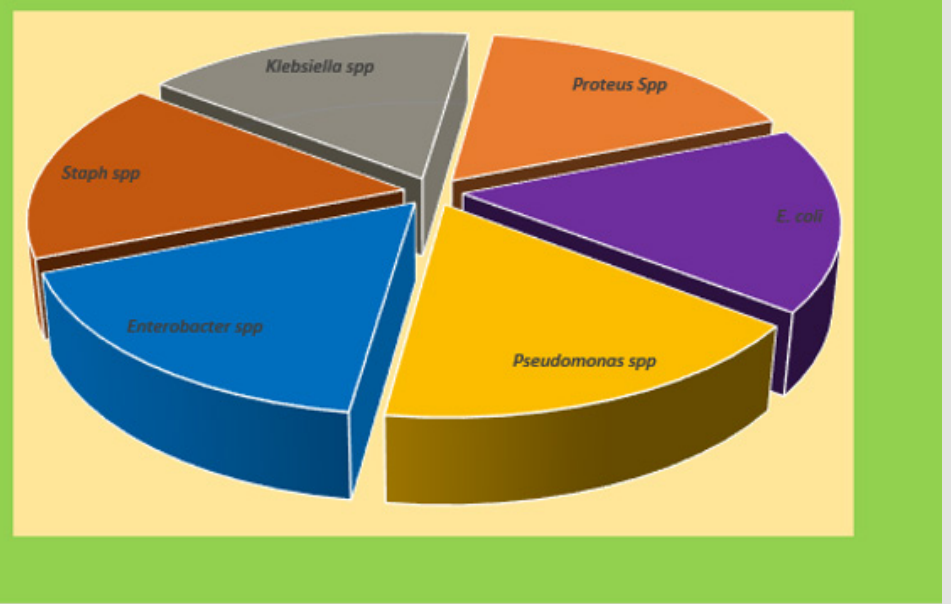

Figure 2: Pie Chart of Possible Isolates from Borehole Water.

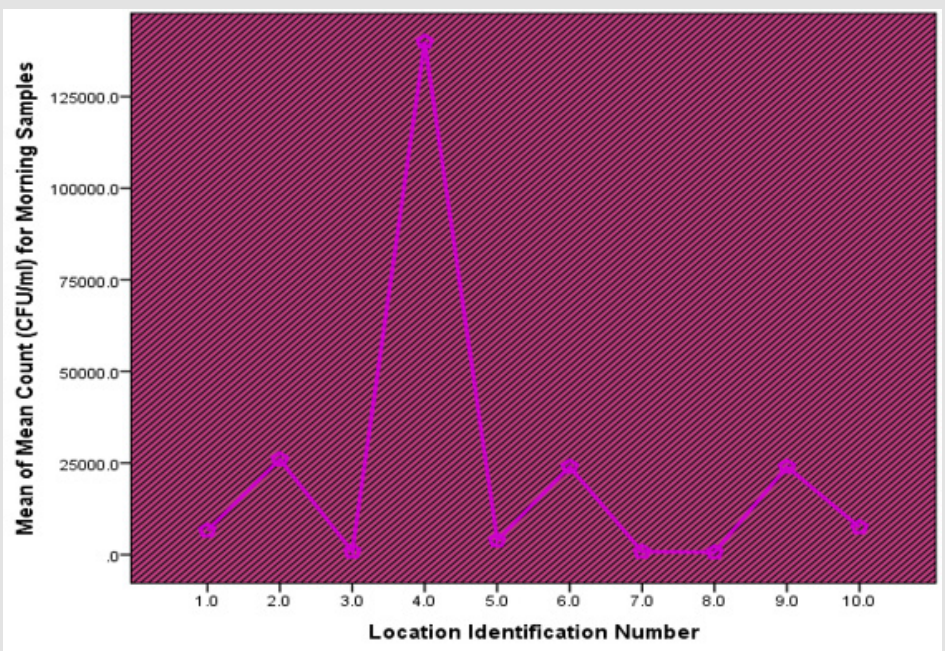

Figure 3: Mean of Mean Count (CFU/ml) for Morning Samples from Ten Locations.

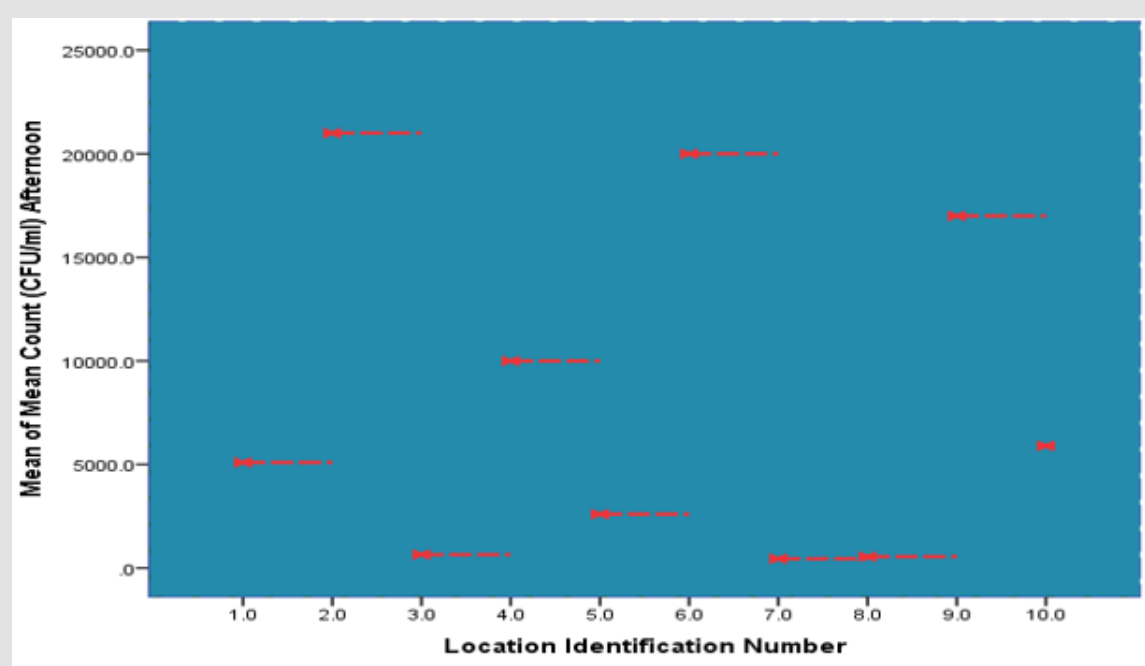

Figure 4: Mean of Mean Count (CFU/ml) for Afternoon Samples from Ten Locations. 
From the result as shown in Figure 5; borehole water samples from Lumumber street and Obidianso street produced acid and gas in the five tubes of the $10 \mathrm{ml}$, four tube each of $1 \mathrm{ml}$ and three cubes each of the $0.1 \mathrm{ml}$, thus their most probable number was 275 . While samples from Obobo lane, five tubes of the $10 \mathrm{ml}$, two tubes of $1 \mathrm{ml}$ and one tube of the $0.1 \mathrm{ml}$ produce acid and gas; thus, the most probable number was 70 . Whereas, samples from Naka Street four tube of the $10 \mathrm{ml}$ and one tube of the $0.1 \mathrm{ml}$ produced acid and gas with 17 as its most probably number. However, samples from Wobo street, Uyo street, Ikon street, Elechi street and Echua street, showed no evidence of acid and gas production in any of the $10 \mathrm{ml}, 1 \mathrm{ml}$ and $0.1 \mathrm{ml}$ tube (Figure 6). Relatively, sample from Lumumber street had the highest mean $\left(2.6 \times 10^{4} \mathrm{cfu} / \mathrm{ml}\right)$ whereas, sample from Azikiwe Street had the lowest mean $\left(6.5 \times 10^{2} \mathrm{cfu} /\right.$ $\mathrm{ml}$ ) from the ten-borehole water sampled in the morning hours. Similarly, sample from Lumumber Street had the highest mean $\left(2.1 \times 10^{4} \mathrm{cfu} / \mathrm{ml}\right)$ while sample from Elechi Street had the lowest $\left(4.5 \times 10^{2} \mathrm{cfu} / \mathrm{ml}\right)$ for samples collected in the evening. Furthermore, samples collected in the evening hours showed Obodo lane to be the highest count $\left(1.8 \times 10^{4} \mathrm{cfu} / \mathrm{ml}\right)$ and Azikiwe Street had the lowest count $\left(3.5 \times 10^{2} \mathrm{cfu} / \mathrm{ml}\right)$. A paired test of Bacterial counts of samples collected at different period of time showed no significant difference ( $p>0.05)$ for pair 1 (Morning*Afternoon) and pair 2 (Morning*Evening) however, the third pair (Afternoon*Evening) revealed a statistically substantial variation $(p<0.05)$ (Table 1).

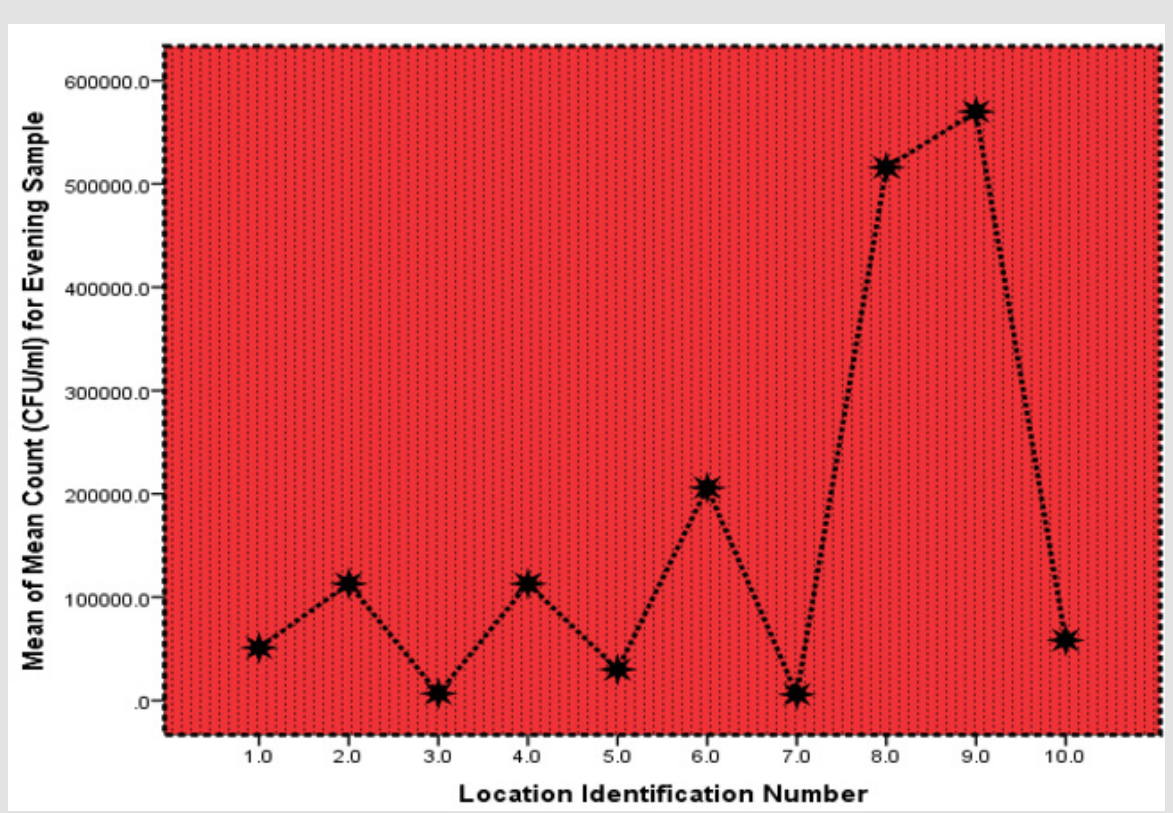

Figure 5: Mean of Mean Count (CFU/ml) for Evening Samples from Ten Locations.

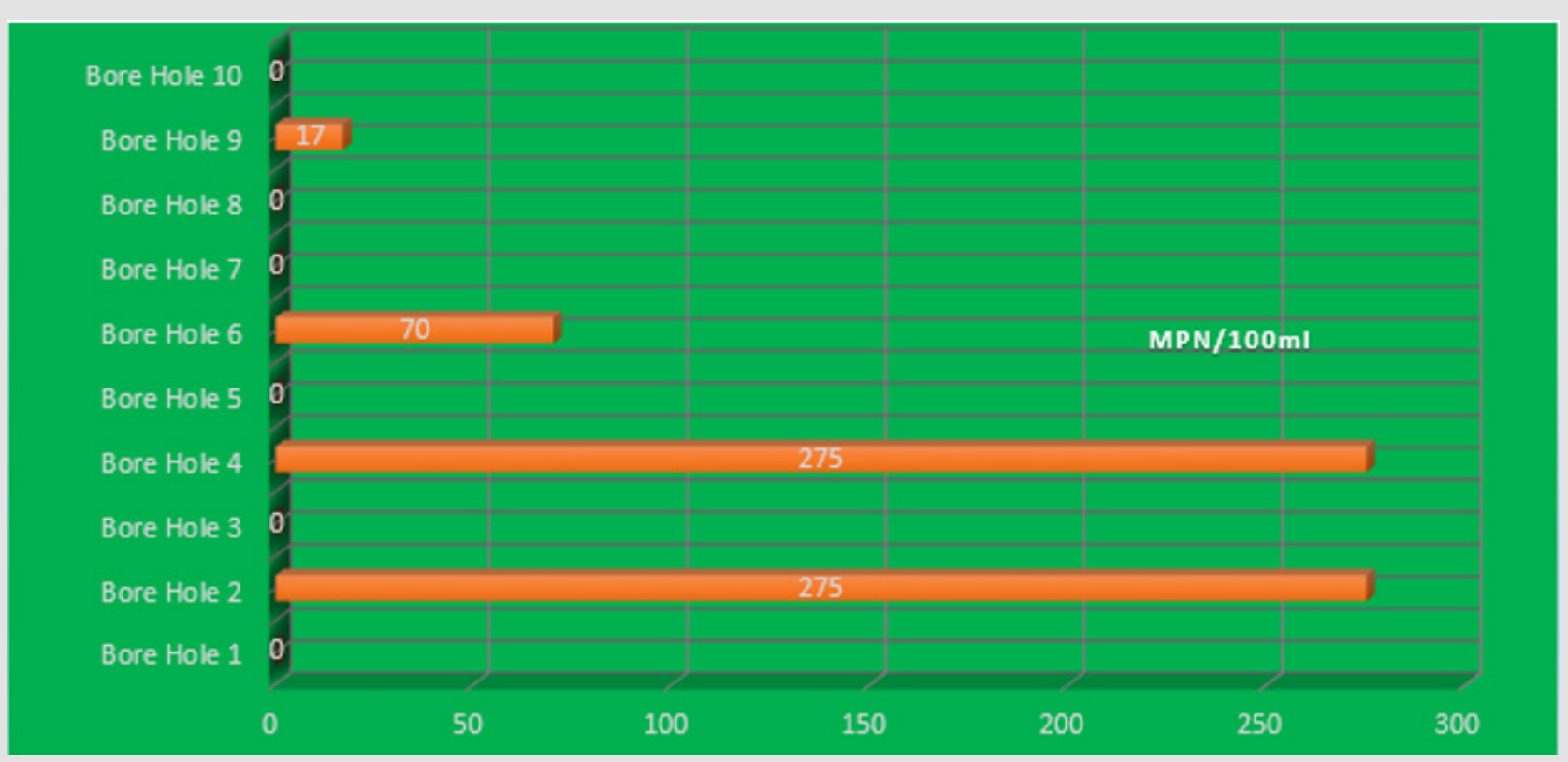

Figure 6: Coliform Enumeration- Most Probable Number (MPN) of the Ten different boreholes sampled. 
Table 1: Paired $t$ test of Bacterial Counts of Samples Collected at Different Period of Time.

\begin{tabular}{|c|c|c|c|c|c|}
\hline Pair Group & Classification & Mean \pm SD $(\mathbf{C F U} / \mathbf{m l})$ & t-value & Df & P-value \\
\hline Pair 1 & Morning*Afternoon & $1.5 \times 10^{4} \pm 4.0 \times 10^{4}$ & 1.181 & 9 & 0.27 \\
\hline Pair 2 & Morning*Evening & $-1.4 \times 10^{5} \pm 2.1 \times 10^{5}$ & -2.142 & 9 & 0.06 \\
\hline Pair 3 & Afternoon*Evening & $-1.6 \times 10^{5} \pm 2.1 \times 10^{5}$ & -2.444 & 9 & 0.04 \\
\hline
\end{tabular}

Also, the study which assumed absence of variations in the mean bacterial counts obtained at various period of time and from the ten different locations when tested revealed contradiction in its assumption of no significant variation $(\mathrm{P}=0.01)$ between the bacterial counts and the period/time of sampled nevertheless, there was a prove of agreement in the hypothesis of no statistical mean disparity $(\mathrm{P}=0.68)$ among the ten different locations sampled as shown on Table 2. The study in a bid to explore the presence of a relationship between Heterotrophic Bacterial Count and period/ time of sampling (Morning, Afternoon \& Evening) with the ten sample locations reported a weak though significant correlation $(\mathrm{r}=0.43, \mathrm{p}=0.02)$; this was established between Heterotrophic Bacterial Count and period/time of sampling (Morning, Afternoon \&Evening) showing a direct relationship also, the coefficient of determination $\left(\mathrm{r}^{2}\right)$ explains $18.5 \%$ of the data variation around the mean. On the other hand, consideration of the sample location reported a negligible positive correlation with no statistical significance ( $r=0.223, \mathrm{p}=0.24$ ) and it was revealed that about $4.9 \%$ of the Heterotrophic Bacterial Count variation was accounted by the sample locations (Table 3).

Table 2: Descriptive Statistics and ANOVA of Period/Time of Sampling and Sample Locations.

\begin{tabular}{|c|c|c|c|c|}
\hline Variable & Classification & Mean \pm 2 SD & F-value & P-value \\
\hline \multirow{3}{*}{ Period/Time of Sampling } & Morning (8.00am-10.00am) & $2.3 \times 10^{4} \pm 4.2 \times 10^{4}$ & 5.125 & 0.01 \\
\hline & Afternoon (12noon-2.00pm) & $8.3 \times 10^{3} \pm 8.2 \times 10^{3}$ & & \\
\hline & Evening (4.00pm-6.00pm) & $1.7 \times 10^{5} \pm 2.1 \times 10^{5}$ & & \\
\hline \multirow{10}{*}{ Sample Location } & Wobo (Location 1) & $2.1 \times 10^{4} \pm 2.6 \times 10^{4}$ & 15320 & 0.68 \\
\hline & Lumumber (Location 2) & $5.3 \times 10^{4} \pm 5.2 \times 10^{4}$ & & \\
\hline & Uyo (Location 3) & $2.7 \times 10^{3} \pm 3.4 \times 10^{3}$ & & \\
\hline & Obidianso (Location 4) & $8.8 \times 10^{4} \pm 6.9 \times 10^{4}$ & & \\
\hline & Ikon (Location 5) & $1.2 \times 10^{4} \pm 1.6 \times 10^{4}$ & & \\
\hline & Obobo Lane (Location 6) & $8.3 \times 10^{4} \pm 1.1 \times 10^{5}$ & & \\
\hline & Elechi (Location 7) & $2.4 \times 10^{3} \pm 3.0 \times 10^{3}$ & & \\
\hline & Azikiwe (Location 8) & $1.7 \times 10^{5} \pm 2.9 \times 10^{5}$ & & \\
\hline & Nanka (Location 9) & $2.0 \times 10^{5} \pm 3.2 \times 10^{5}$ & & \\
\hline & Echue (Location 10) & $2.4 \times 10^{4} \pm 2.9 \times 10^{4}$ & & \\
\hline
\end{tabular}

Table 3: Correlation Analysis of Heterotrophic Bacterial Count with Period/Time of Sampling and Sample Location.

\begin{tabular}{|c|c|c|c|c|c|}
\hline Variable & Classification & $\mathbf{R}$ & $\mathbf{r}^{2}$ & P-value & Remark \\
\hline Heterotrophic Bacterial Count & Period/Time of Sampling (Morning, Afternoon \&Evening) & 0.430 & 0.185 & 0.02 & Significant \\
\hline Heterotrophic Bacterial Count & Sample Location $(1,2,3,4,5,6,7,8,9 \& 10)$ & 0.223 & 0.049 & 0.24 & Not Significant \\
\hline
\end{tabular}

\section{Discussion}

The present investigation has revealed the presence of aerobic heterotrophic bacteria and coliform bacteria in various borehole water sample in Diobu district of Port Harcourt metropolis. Water suitable for human consumption (potable water) should be free from disease causing organisms, as well as large numbers of nonpathogenic organisms. The borehole water from six locations (Wobo street, Uyo street, Ikon street, Elechi street, Azikiwe street, and Echua street) had considerable lower heterotrophic bacterial counts and total coliform counts and could be concluded to be of better quality for domestic use than samples from Lumumba, Obidianso, Obobo lane and Nanka street which had much higher counts of both bacteriological parameters. Therefore, it can be concluded that water from all the boreholes investigated are not suitable for drinking without treatment process so as to kill or inactivate the pathogens [35]. WHO and United State Environmental Protection Agency Standard for faecal coliform in drinking water is zero coliform? Therefore, waters from all the boreholes should be properly treated before use to avoid the potential outbreak of water borne epidemic.

The observation in this study supports the fact that high heterotrophic count in water reflects high coliform count.

The presence of high coliform count reported in some boreholes in this present study could probably be attributed to the proximity 
of these boreholes to septic tank located near the boreholes and the general unhygienic and poor sanitary environment surrounding the boreholes, this agrees with Bello et al. [17]. Moreover, shallow depth of less than $40 \mathrm{~m}$ could be the problem because it contradicts the 40 $\mathrm{m}$ minimum depth recommendation. Depth is an issue as reported by previous studies $[12,11]$. Though the depths of the various boreholes studied were unknown, borehole depth is an imperative factor in the investigation of bacterial contaminants in borehole water. Furthermore, it could probably be that the pipes used for water distribution were bad thus, allowing seepage of microbial contaminants into the boreholes, it was strongly suggested that damaged pipes allow leakage causing contamination of microbial pathogens into the body of aquifer as seen in this study and a previous study by Ibe et al. [19] reported same trend as a major factor to be considered when planning for potable water safety. These and other human activities could have probably contributed to water contamination as revealed in other studies $[13,14]$.

In addition, the bacterial isolated from the water belong to the genera of potential pathogenic bacteria, hence it is recommendation that water from all the boreholes need to be boiled before use. There is need to increase the awareness of the public towards the dangers associated with the use of contaminated water; the danger in construction of a septic tank near a water source and vice versa is of public health importance. Sample from Lumumber street had the highest mean heterotrophic bacterial count whereas, sample from Azikiwe street had the lowest mean heterotrophic bacterial count from the ten-borehole water sampled in the morning hours. Similarly, sample from Lumumber Street had the highest heterotrophic bacterial count while sample from Elechi Street had the lowest heterotrophic bacterial count for samples collected in the evening. Furthermore, samples collected in the evening hours showed that Obodo lane had the highest heterotrophic bacterial count and Azikiwe street had the lowest count. The result from this study shows that water sampled from Lumumber borehole had the highest heterotrophic count in this study meaning the microbial contamination in this borehole water is much as compared to that in the other sites as contained in this study.

This agrees with the work of Legros et al. [24] which reported the presence of microbial contaminants in drinking water in Uganda; also, in Nigeria, according to the epidemiological survey by the Federal Ministry of Health of Nigeria [22]. Similarly, LeChevallier et al. [25] reported microbial contamination in drinking water which lead to water borne diseases. Furthermore, Cowan et al. and Edberg et al. [25-26] also reported the presence of E. coli in drinking water in their separate studies. However, this was not the case in Azikiwe and Elechi streets as these borehole water showed lowest heterotrophic count in the morning and evening period in which case Azikiwe maintained lowest count in two intervals (morning and afternoon). This lowest level of microbial loads makes this borehole better than the others with higher microbial count thus, it can be said that the contamination due to microorganisms is reduced as compared to other boreholes water tested in this study. Heterotrophic counts for the three sessions (morning, afternoon and evening) of sample collection showed samples collected in the afternoon to have the highest grand mean compared to samples collected in the morning and evening periods; also, the evidence of a statistically significant correlation between heterotrophic count and the period/time of sample collection (session) is a prove of a relationship.

This is similar to the work of Bello et al. [17] which reported on the effect of climate on microbial contamination of drinking water due low microbial replication at high temperature. Nevertheless, in the same view, the study of Azuonwu et al. [38] reported the upshot of meteorological conditions on microbial contamination of drinking water owing to decreased replication of microorganisms in relation to high thermal condition and this aids disinfection of potable water. Furthermore, seasonal session affects ground water quality according to prior studies which are inconformity with this present study, which is also in line with the study of Trivede et al.; [9] and Vaishali et al. [10]. Hence, the variation found in the microbial counts in the various borehole water sources support the notion that underground water quality varying from place to place which could be due soil types, rocks and surface through which it flows as reported by some studies [9-12]. The area of this present study (Diobu) has a soil type topography within its environ which has not been consolidated, it is temperately porous and made up of permeable sands with the high propensity to rapidly drain its content thereby making even the borehole water probably disposed to contamination over time of long exposure.

The coliform enumeration (Most Probable Number) reported in this study showed that four, out of the ten borehole water sampled contained microbial load which make these borehole water not good for consumption with borehole water from Lumumber street and Obidianso street been the most unsuitable borehole water for human consumption, followed by borehole water from Obobo lane and Naka street whereas, others showed no evidence of contamination which prove their suitability for human consumption and domestic use. Using the commonly risk classification which is based on the number of indicator organisms in a $100 \mathrm{ml}$ sample according to Cowan and Steel; APHA, [35-39] respectively. Lumumber street and Obidianso street borehole water were classified as "high risk" or "very high risk" because the indicator organisms present in the borehole water samples were over a hundred per one hundred millilitres of sample of water. In addition, Obobo lane and Naka borehole water were categorized as "medium risk" whereas, the other six borehole water was classified as "very low risk".

Based on this classification only the six-borehole water classified as "very low risk" seem to be potable for consumption which comprises of the borehole water from Wobo, Uyo, Ikon, Elechi, Azikiwe, and Echue. Nonetheless, risk classification of 
faecal indicator bacteria (FIB) in drinking water are imperfect and their level does not necessarily equate to risk [32]; since quality varies both temporally and spatially, occasional sampling may not accurately reflect actual exposure. Moreover, source indicator i.e. sanitary inspection (hazards identification and hygienic checks) of both the water and its surrounding is a complementary approach in the assessment of safe drinking water in a cosmopolitan society like ours with massive anthropogenic activities.

\section{Conclusion}

The building of borehole requires underground pipe laying which supposedly need to meet up with its minimum requirement of Health and Safety rules; also, periodic maintenance, dumpsites, pit latrines, suck-away and drainages ought to be far from borehole water pipes to avoid cross contamination, this was likely not the case in some of these areas thus, making the quality of borehole water and its potability in-doubt. Consequently, both the water for home use and the commercially sold water quality was not guaranteed. In the midst of the increasing demand for water in Diobu area due to the high number of people and its commercial activities, the people look out for availability of water only, irrespective of the quality. This proves the fact that access to water may not guarantee water potability for consumption and use. Nonetheless, this is a strong side-line of Public Health concern, because consumption of anunsafe water could lead to water borne diseases thereby, increasing the burden of disease epidemic outbreak especially among the vulnerable ones, like the children in our Communities. However, the collective result from this study showed a strong need for prompt and regular risk evaluation of microbial contamination of borehole water since citizens residing and those doing all kind of businesses in this area make use of this water ignorantly, not knowing the health implication it could pose in their health.

It is therefore, strongly recommended that borehole water sources within the Diobu axis be properly and routinely investigated, even as the water should be treated accordingly, to improve the microbial water quality. Also, periodic maintenance should be carried out to avoid damages to the pipes and other materials. Furthermore, the borehole water without contamination as reported in this study should continually be checked and monitored over time for its portability to be retained, and good environmental sanitation strategy should be provided and subsequently be maintained, so as to keep our drinking water sources safe for the entire populace especially, for those within this area, bearing in mind that water is a fundamental human social right and thus, every human must have access to safe drinking water as declared by United Nation bill of right of 1948. Nonetheless, it will not be out of place still, for the Local, Regional and National Government of the region to embark on construction and provision of well treated potable water for her citizens, it is firmly believed that such dynamic leadership steps would certainly reduce the trend of water based, water wash and water borne infection in the country in general, and in return, the ripple effects of such gesture would be a healthy nation and high level of productivity in all strata of human endeavors.

\section{Acknowledgement}

We are profoundly grateful to Prof. S.D Abbey, Prof. G.N Woken, Azuonwu, Flourish and Dr Azuonwu, Goodluck for their prayers and support, even as we are sincerely grateful to the Microbiology Laboratory staff of the University of Port Harcourt Teaching Hospital. The technical staff of ICT Department of the Rivers State University is also appreciated for their assistance during the sourcing and assemblage of the literature materials for the write-up.

\section{Conflict of Interest}

None observed among authors.

\section{References}

1. World Health Organization (2002) Water for Health enshrined as a human right. Geneva [Retrieved March 26 $6^{\text {th }}, 2019$ http:// www.who.int/ mediacentre/news/releases/pr91/en] from (2010).

2. WHO/UNICEF (2010) Joint Monitoring Programme for Water Supply and Sanitation, 2010 estimates for water and sanitation.

3. Howard KWF (1997) Impacts of urban development on groundwater In: Eyles E., editor. Environmental Geology of Urban Areas. Special Publication of the Geological Association of Canada; St. John's, Nfld, Canada, 3. pp. 93-104.

4. (2001) Department of International Development (DFID), Strategies for Achieving the International Development Targets. Department of International Development; Addressing the water crisis: Healthier and more productive lives for poor people, London, UK.

5. Mac Donald AM, Davies J (2002) A Brief Review of Groundwater for Rural Water Supply in Sub-Saharan Africa. British Geological Society; Nottingham, UK.

6. Harvey PA (2004) Borehole sustainability in rural Africa: Analysis of routine field data; Proceedings of 30th WEDC International Conference; Lao PDR, Vientiane.

7. UNICEF (2007) Water, Sanitation and Hygiene in Nigeria. UNICEF Information Sheet.

8. Aiyesanmi AF, Ipinmoroti KO, Oguntimehin II (2004) Impact of automobile workshop on groundwater quality in Akure metropolis. J Chem Soc Nig (Supplement to 2004 proceeding) pp. 420-426.

9. Trivede P, Bajpai A, Thareja S (2010) Comparative study of seasonal variations in physico-chemical characteristics in drinking water quality of Kanpur, India with reference to 200 MLD filteration plant and groundwater. Natural Science 8(4): 11-17.

10. Vaishali P, Punita P (2013) Assessment of seasonal variations in water quality of River Mini, at Sindhrot, Vadodara. Int J Environ Sci 3(5): 14241436.

11. Seth ON, Tagbor TA, Bernard O (2014) Assessment of chemical quality of groundwater over some rock types in Ashanti region, Ghana. Am J Sci Ind Res 5(1): 1-6.

12. Thivya C, Chidambaram S, Thilagavathi R, Nepolian M, Adithya VS (2014) Evaluation of drinking water quality index (DWQI) and its seasonal variations in hard rock aquifers of Madurai District, Tamilnadu. Int J Adv Geosci 2(2): 48-52.

13. Govindarajan M, Senthilnathan T (2014) Groundwater quality and its health impact analysis in an industrial area. Int J Curr Microbiol App Sci 3(7): 1028-1034. 
14. Moyo NAG (2013) An analysis of the chemical and microbiological quality of ground water from boreholes and shallow wells in Zimbabwe. Phys Chem Earth 66: 27-32.

15. Odukoya OA, Arowolo TA, Bamgbose O (2002) Effect of solid waste Landfill on underground and surface water quality at Ring Road, Ibadan. Global J Environ Sci 1(1): 43-52.

16. Nash H, Mc Call GJ (1994) Groundwater Quality. Chapman \& Hall, London, UK.

17. Bello 00, Osho A, Bankole SA, Bello TK (2013) Bacteriological and physicochemical analyses of borehole and well water sources in IjebuOde, Southwestern Nigeria. Int J Pharm Biol Sci 8(2): 18-25.

18. Van Vuuren L (2013) Institutional conundrum sinking groundwater supply in North West Town. Water Wheel 12(6): 17-19.

19. Ibe SR, Egereonu UU, Sowa AHO (2002) The impact of hand pump corrosion on water quality in rural areas of West African sub-region. Environ Monitoring Assess 78: 31-43.

20. Ateba CN, Maribeng MD (2011) Detection of Enterococcus species in groundwater from some rural communities in the Mmabatho area, South Africa: A risk analysis. Afr J Microbiol Res 5(23): 3930-3935.

21. Mark WR, Ximing Cai, Sarah AC (2002) World Water and Food to 2025 Dealing with security, International food policy research Institute, NY Washington, DC, USA

22. (1991) Federal Ministry of Health of Nigeria, WHO/UNICEF/USAID/ CCCD. Lagos: Nigerian Control of Diarrhea Diseases Programme, 19911995. Federal Ministry of Health, Lagos, Nigeria.

23. Alabi SA, Audu RA, Oyedeji KS, Mafe AG, Uhuangho JE (1998) Viral, bacterial and parasitic agents associated with infantile diarrhea in Lagos. Nig J Med Res 2(1/2): 29-32.

24. Legros D, Mc Cormick M, Mugero C, Skinnider M, Bek'obita DD, et al. (2000) Epidemiology of cholera outbreak in Kampala Uganda. East Afr Med J 77(7): 347-349.

25. LeChevallier MW, Welch NJ, Smith DB (1996) Full-scale studies of factors related to coliform re-growth in drinking water. Appl Environ Microbiol 62(7): 2201-2211.

26. Edberg SC, Allen MJ, Smith DB (1988) National field evaluation of a defined substrate method for the simultaneous enumeration of total coliforms and Escherichia coli from drinking water: comparison with the standard multiple tube fermentation method. Appl Environ Microbiol 54(6): 1595-1601.

\section{ISSN: 2574-1241}

DOI: $10.26717 /$ BJSTR.2020.24.004093

Azuonwu Obioma. Biomed J Sci \& Tech Res

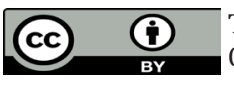

This work is licensed under Creative Commons Attribution 4.0 License

Submission Link: https://biomedres.us/submit-manuscript.php
27. Edberg SC, Rice EW, Karlin RJ, Allen MJ (2000) Escherichia coli: the best biological drinking water indicator for public health protection. J Appl Microbiol 29(S): 106-116

28. Isaäcson M, Canter PH, Effler P, Arntzen L, Bomans P, et al. (1993) Haemorrhagic colitis epidemic in Africa. Lancet 341(8850): 961.

29. Lechevallier MW, Evans TM, Seidler RJ, Daily OP, Merrell BR, et al. (1982) Aeromonassobriain chlorinated drinking water supplies. Microbial Ecol 8(4): 325-333.

30.(2006) World Health Organization, Guidelines for Drinking Water Quality: Incorporating $1^{\text {st }}$ and $2^{\text {nd }}$ Addlenda, Vol.1 Recommendations $\left(3^{\text {rd }}\right.$ Edn.), Geneva, Switzerland.

31. Abogan OS (2014) Sanitation and Personal Hygiene: Antidote to Cholera Epidermic Outbreak in Challenging Environment in Nigeria. Global Journal of Human Social- Science B: Geography, Geo-Sciences, Environmental Disaster Management 14(1): 1-7.

32. Warner D (1998) Drinking water supply and environmental sanitation for health. Presented at the International conference for sustainable development, Paris, Italy.

33. Nola M, Njine T, Djuikom E, Foko VS (2000) Bacteria indicators dynamics in wells as influenced by well depth and well water column thickness, in Yaounde (Cameroon). Afr J Sci Tech 1: 82-91.

34. Cheesbrough M (2000) Medical Laboratory Manual for Tropical Countries (Vol. II). Butterworth \& Co. Publishers, Great Britain.

35. Andrew D Eaton, American Public Health Association, American Water Works Association, Water Environment Federation (2005) Standard Methods for the Examination of Water and Wastewater. (21 $1^{\text {st }}$ Edn.), APHA, AWWA, WEF; Washington, DC, USA.

36. Fawole MO, BA Oso (2001) Laboratory Manual of Microbiology. Ibadan, Nigeria (Spectrum Books) p. 15-45.

37. Burnett SL, Beuchat LR (2001) Human Pathogens associated with raw produce and unpasteurized juices, and difficulties in decontamination. Journal of Industrial Microbiology and Biotechnology 27(2): 104-110.

38. Azuonwu, O, Chikanka AT, Omowumi OA (2017) Alteration of Bacteriological load quality of rainwater due to atmospheric exposure: A synergy to potable water disinfection in remote Community of Niger Delta of Nigeria. Ann Clin Lab Res 5(2): 166.

39. Cowan ST (1974) Cowan and Steel's Manual for identification of medical bacteria. ( $2^{\text {nd }}$ Edn.), Cambridge University Press, London, UK, p. 67-83.

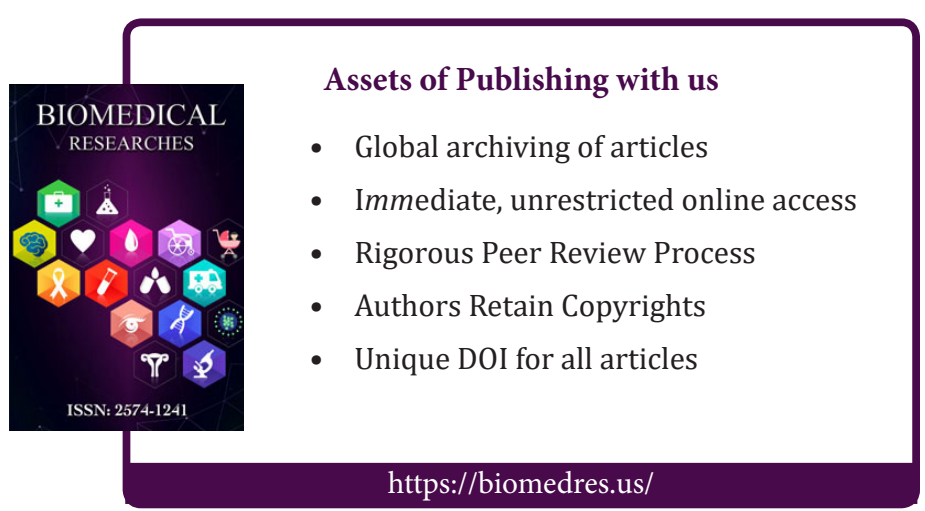

